\title{
Religious Buildings of the Period of an Early Russian Neogothic Style (the Second Half of XVIII - the early XIX centuries)
}

\author{
Igor Yamshanov ${ }^{1, a}$ and Olena Oliynyk ${ }^{2}$ \\ ${ }^{1}$ St.Petersburg State Polytechnical University, Politekhnicheskaya ul., 29, 195251, SaintPetersburg, Russia \\ ${ }^{2}$ National Aviation University, Kosmonavta Komarova, 1, Kiev, 03680, Ukraine
}

\begin{abstract}
The article is devoted to the development of religious buildings of Neogothic style and their stylistic features in the second half of the XVIII century. Each new building of this period has an unusual combination of new compositional techniques that illustrates the continuity of architects creativity who wanted to create something new and different, but at the same time causing the association with the Middle Ages.
\end{abstract}

\section{Introduction}

For cult buildings of early Neogothic style in the second half XVIII - the early XIX century was unusual interpretation of Gothic shapes. According to the volume and planning decisions they had almost nothing in common with Gothic cathedrals of the Middle Ages. During this period construction of orthodox churches with the use of Neogothic forms obviously prevailed.

\section{The first orthodox churches of Neogothic style in the Russian Empire}

The first orthodox churches of Neogothic style in the Russian Empire appeared in Moscow region. It is possible that the earliest of them is St. Nicholas church on Starki's (Figure 1-2) country churchyard in Cherkizovo built possibly on Bazhenov's project in 1759-1763. However, at this point it is not determined exactly when the temple got Neogothic features. Whether there was it at construction in the late fifties, or it got them as a result of rebuilding after construction of a belltower (Figure 1) in the 1780th. The decorative lancet arches decorating a drum of the dome, blind lancet arcade at the top of the quadrangle and pillars, trailing angles of the same quadrangular, the crown of pinnacles around the dome with a sharp spire belong to Neogothic elements of church.

With regard to the structural system of religious buildings in the style of early Russian Gothic Revival features are the following: building walls, made mostly of brick (stone was rarely used); vaults are often either closed, or the type of groined; dome usually coated with metal sheets are bulbous, hemispherical or baroque form.

The decision of the facade, without exception, of the churches were built in the 2 nd half of the XVIII century, maintains strict symmetry, indicating the significant influence of the classicism.

\footnotetext{
${ }^{a}$ Corresponding author : dartigor@mail.ru
} 


\section{MATEC Web of Conferences}

Facade compositions with completely different themselves, bearing different unique features. There are churches with one and five domes, with a bell tower, included in the volume of a temple or standalone, without the bell tower at all or with two ones. The same diversity is observed in the planning solution. There are oval, rectangular, cross-shaped plan, in the form of a quatrefoil plan, simple and complex.
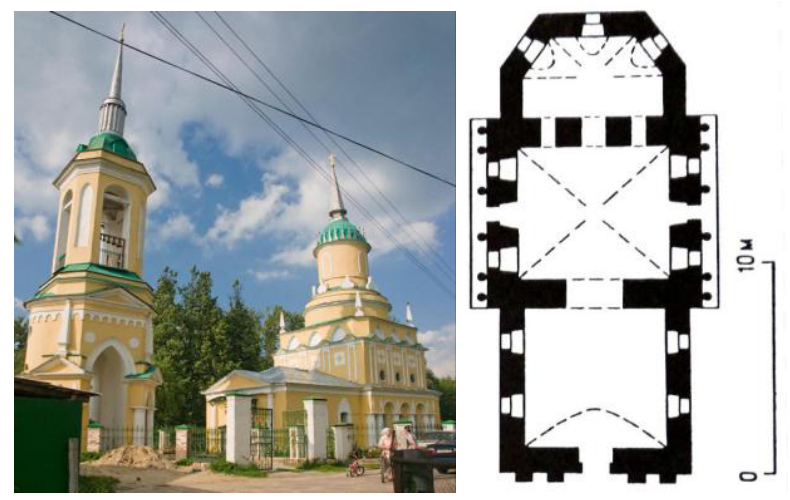

Figure 1, 2. The Church of St. Nicholas, 1759-1763. Cherkizovo-Starki. The architect Vasily Bazhenov (?). View from the southwest. Plan.

In this historical period, we almost do not see a direct continuity in development of the style in the form of planning and facade solutions of the projects of earlier buildings, with the exception of the Church of the Archangel Michael in Podzhigorodovo (Figure 3, 4) (1763) in Moscow, and in the church Signs Veshalovka (Figure 5) (1768-1784) in the Lipetsk region, where a commonality in space-planning, and the facade decision is clearly visible. This is an example of how a simple project has evolved and been enriched in the plastic, and the three-dimensional solutions. The main volume of the church in Veshalovka was supplemented by four corner towers with high spires, and the porch of the apse and gable not blocked and eight-pitched roofs, and are accordingly not one, but three gable, decorative pointed arches. Windows-lucarnes, cutting through the arch, are more ornate frames, and the whole facade decoration is much more finely crafted and is more expressive.

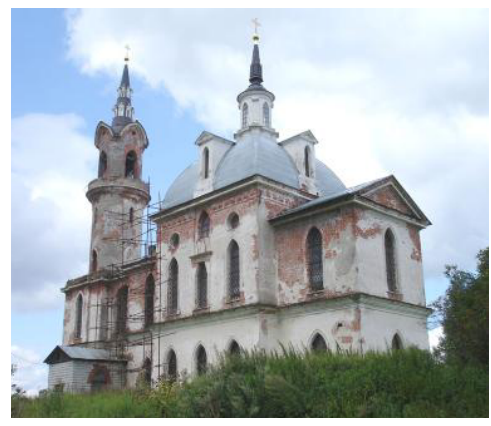

Figure 3. Church of the Archangel Michael. Podzhigorodovo. 1763 View from the southeast.

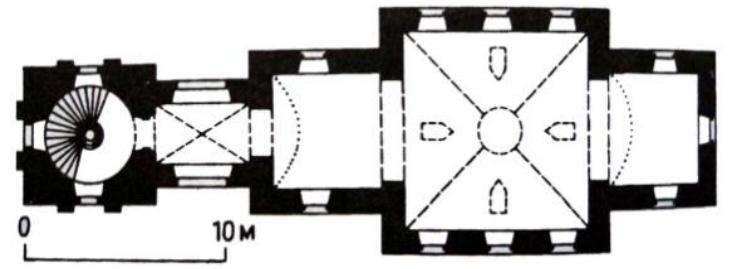

Figure 4. The Church of the Archangel Michael. Podzhigorodovo. 1763 Plan. 


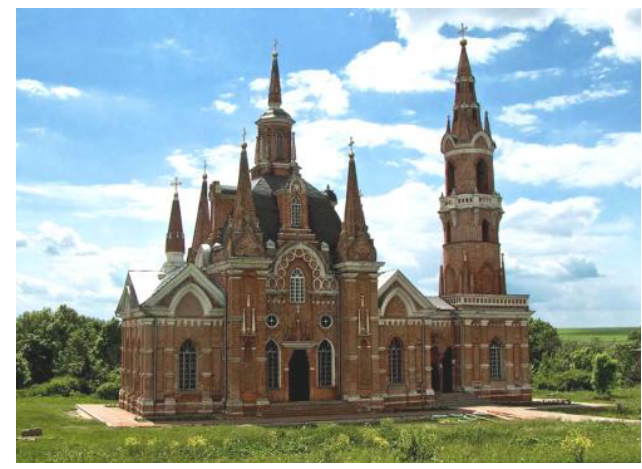

Figure 5. Church of the Sign. Veshalovka. 1768-1784. The architect Vasily Bazhenov (?). North façade.

The facade of the church has a vertical three-part division, and it is stored in the structure and elements of its form. So facade itself consists of a central part, complete lancet kokoshnik and two towers topped with spiky octagonal spires. Towers also have tripartite division, their corners are decorated with pilasters, and its central part is further decorated with graceful turret with a spire and pinnacles. The vertical aspiration is vividly expressed in every part. With great finesse made the central part of the side facades. They have one portal flanked by a pair of lancet windows, above which is located a pair of circular openings, and the central part of the portal is decorated with vimpergs made of red brick, which is located on the lancet window. This window has a frame in the form of rings of the "white stone" with adjoining archivolt. This archivolt with a belt rings form a sort kokoshnik completing the central part of the facade. The crowning element of the central part of the facade, the final total vertical operation, is a window-lucarnes lancet form, located above kokoshnik. The total composite structure of the facade is characterized by a dynamism in the construction of forms.

At the beginning of the XIX century, a type of centric church building, typical to the early Russian Neogothic style, receives a distribution. This type of temple has square plan, topped by a hemispherical dome on a low drum. However, in this case the continuity possible to speak of only in part, because of a completely different interpretation of the façade decoration. Four churches of this type have been identified. The first of them - is the Church of the Ascension in the village Peremilovo (Figure 6,7.), it was built in 1792. The second is a baptismal church of the Kazan Church Puchkovo village (Figure 8.), built in 1802. The third is the church of St. Nicholas in Rzhavki (Figure 9), (1805, 1818-1820), supplemented by a free-standing bell tower (Figure 9). The last of them is the church of St. Nicholas in the Simonov monastery, built in 1834, has a lateral extension which housed communal cells.

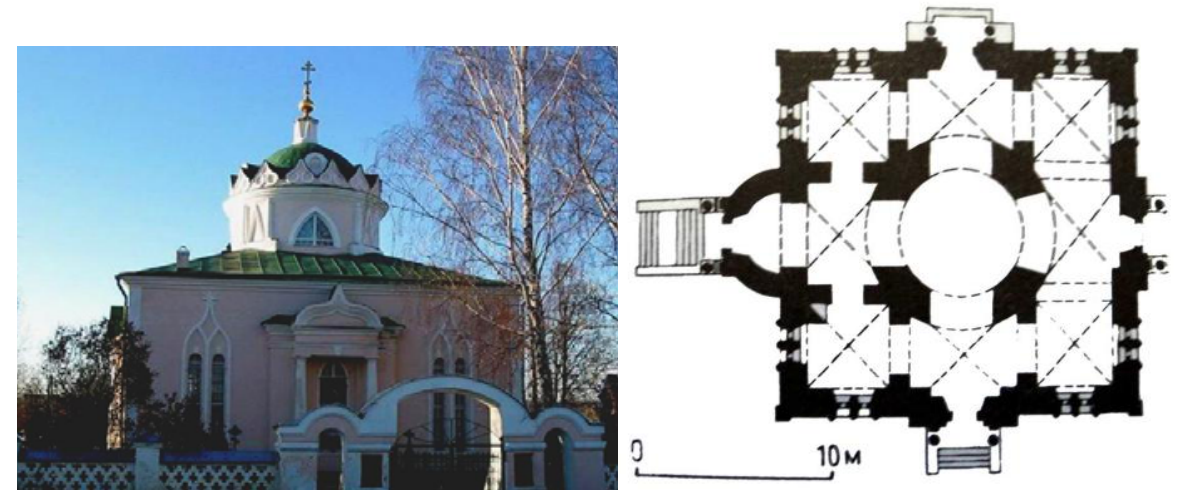

Figure 6, 7. The Church of the Ascension. Village Peremilovo of S.S. Apraksin. 1792. Architect F. Kamporezi. The western facade. Plan. 


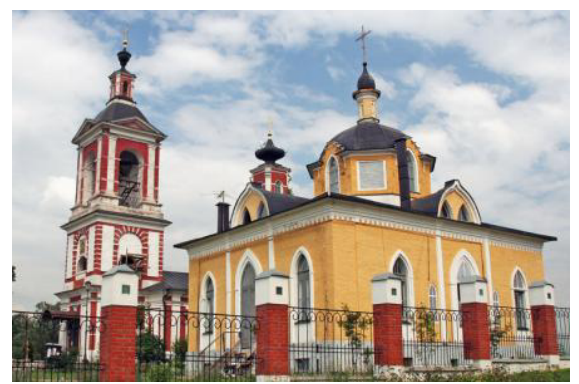

Figure 8. Baptismal Church of the Kazan church. Village Puchkovo. 1802.

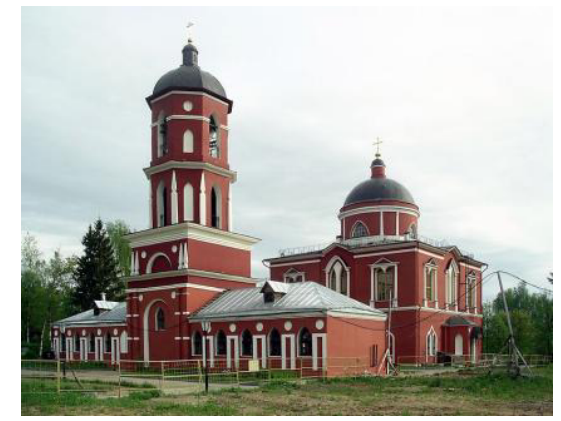

Figure 9. Church of St. Nicholas. Rzhavki. 1805 1818-1820.

There are examples of almost identical buildings, and only decorative details vary. Thus was copied famous Chesma Church (Figure 10-12) in St. Petersburg, designed by Y.M. Felten. And it was copied twice. The first copy of the church, built in the 1781-1784, was in the village Posadnikovo ( 13,14) Pskov province Manor A.D. Lanskoy (to this day has not been preserved), while it was supplemented by a free-standing bell tower (Figure 13,14), that was absent in the original; the second is located in the village Krasnoe (15-18) Tver region - it is the Church of the Transfiguration, the work of Felten, built in 1790 in the estate Poltoratsky. All this indicates the absence of a single historical prototype, which could serve as a basis for the design of the Orthodox churches in the early Gothic Revival style. Also, there is almost no direct continuity in the evolution of forms of Gothic Revival architecture of religious buildings in the period under review. Each new building has an unusual combination of new compositional techniques that illustrates the continuity of creativity of architects who wanted to create something new and different, but at the same time causing the association with the Middle Ages. In some cases, creating the impression of antiquity, in the other the impression of solemnity.

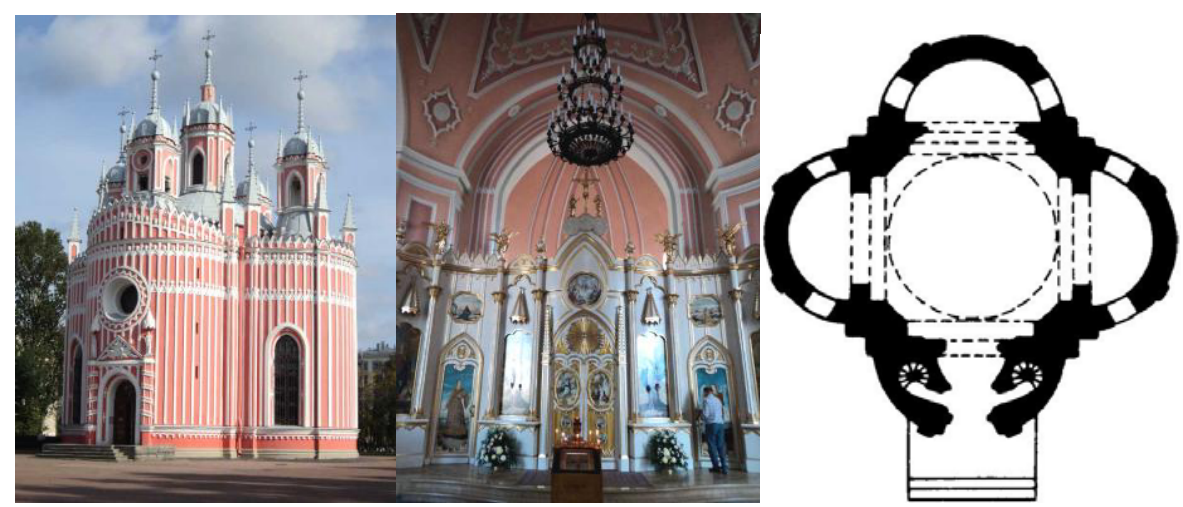

Figure 10, 11, 12. Cesma Church. St. Petersburg. 1777-80. The architect Y.M. Felten. View from the southwest. Interior. Photo by author 2010. Plan. 

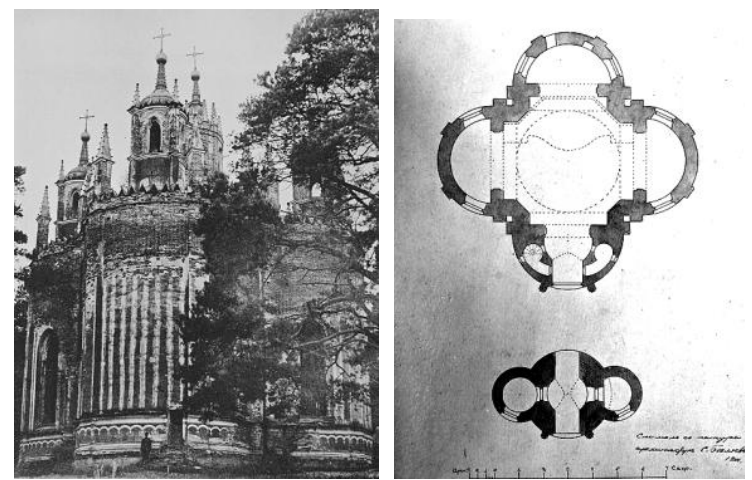

Figure 13, 14. The St. Nicholas Church. Posadnikovo. Manor A.D. Lanskoy 1782-84. General view. Plan.
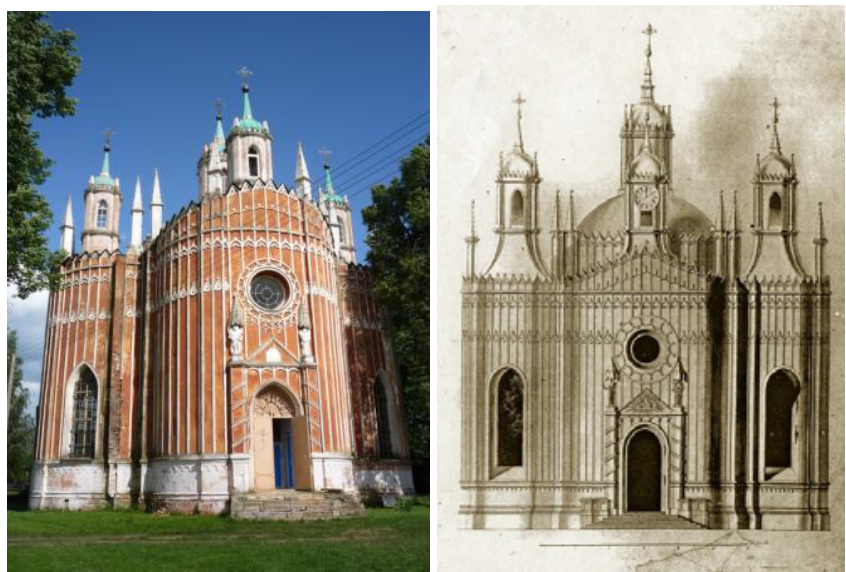

Figure 15, 16. Savior Transfiguration Church. Krasnoe Village. View from the west. The project of the western facade, the drawing late XVIII century. (Poltoratsky archive)
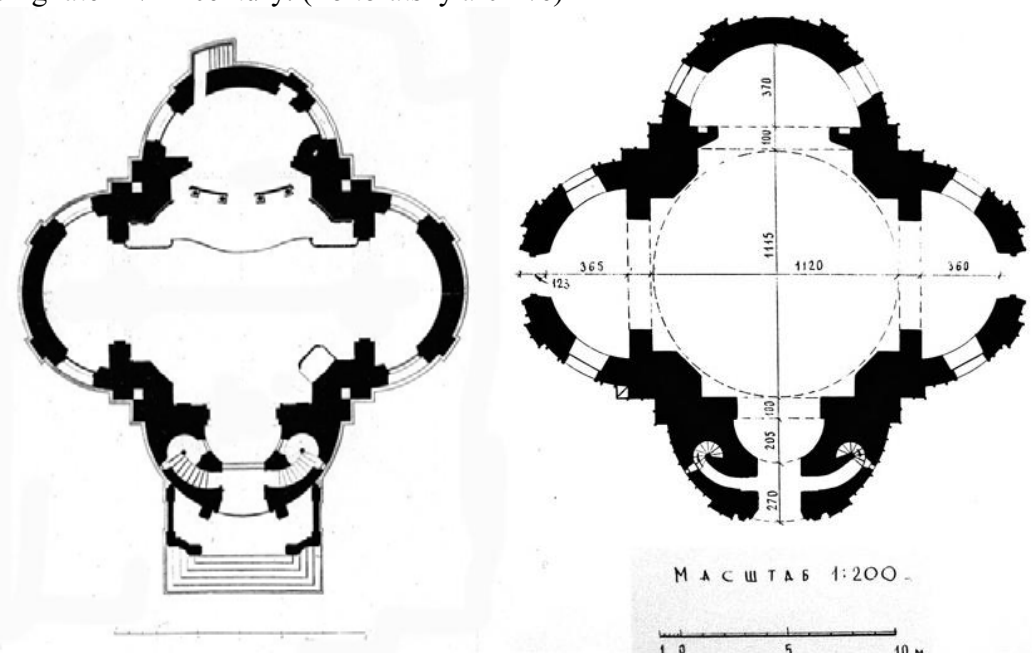

Figure 17, 18. Savior Transfiguration Church. Krasnoe Village. The project plan, the drawing late XVIII century - left. (Poltoratsky archive) modern plan - right. 
The construction of churches of other Christian confessions is practically not conducted, with rare exceptions, an illustration of this is a Lutheran church of St. Peter in the village Malye Kolpany (Figure 19, 20) at Gatchina, completed in 1800. It was built by unknown architect since 12 July 1789 but work was suspended. Its construction was completed in the 1799-1800 under the leadership of Andreian Dmitrievich Zakharov. The consecration of the church took place on February 2 1802. Kirch was entirely built of stone. It belongs to the nasal type, with rectangular apse and a square plan bell tower, which once topped with high iron spire, the top of which is decorated with a gold-plated ball and cock, made a drawing by Zakharov in 1800. Of all the religious buildings built in the first period of the development of the Neogothic style in Russia it is closest to its historical prototype - European medieval parish church.
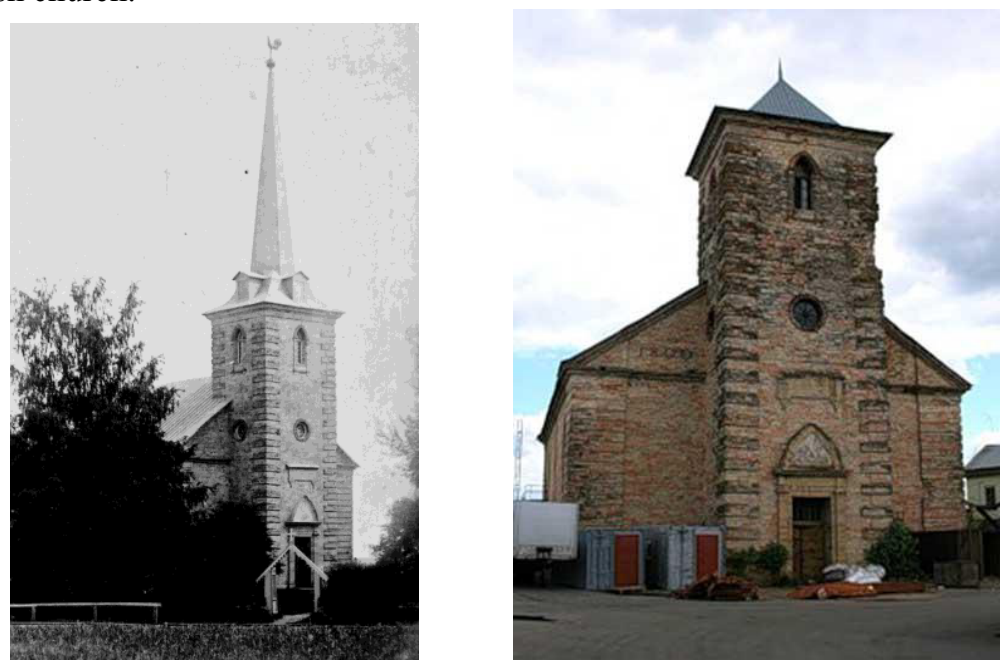

Figure 19, 20. Lutheran Church of St. Peter. village Malye Kolpany at Gatchina. 1800. The architect A.D. Zakharov. Photo of the early XX century. West façade.

\section{Orthodox church of the early Russian Neogothicperiod, erected in Moscow and Moscow region}

A typical example of the application of Neogothic forms in Russian architecture is the church of St. Nicholas in the churchyard Starkey (Figure 1,2) in the village of Cherkizovo, built in the forms close to the works of V.I. Bazhenov in 1759-1763. There is also speculation that the project could have belonged to someone of his students. This church was built at the expense of Prince Cherkassky P.B. It is a small cube-shaped temple, covered with closed vault topped with a hollow decorative drum that completed high spire. The walls of the bulk of the temple are decorated with Gothic arches and niches, and the north and south facades are also false arcades. From the west the temple has the refectory of smaller height, the entrance to which is decorated with a portico of Tuscan order. Inside the church is preserved wooden iconostasis, also designed in the Gothic Revival style. The free-standing bell tower was build in 1780 (Figure 1), a constructive basis of it consists of four pylons, it completed with high spire. St. Nicholas Church was not rebuilt in the following years, thereby its original layout structure was preserved. An example of an ascetic approach to the decoration of facades is the church of St. Archangel Michael (Figure 3,4) in Podzhigorodovo. V.G. Lisowski dates the construction of the church by 1763. The construction of the church of the Archangel Michael, was started by order of the owners of the village, the brothers A.M. and P.M. Jurjev. I personally, as well as M.G. Baranova, support the opinion of V. Lisowski, since his research is supported by the inscription on the wall of the church wich dates it by the year 1763. The temple project was attributed to the famous Russian architect Vasily Bazhenov, but there is also the likelihood that the project belonged to someone from the architect's students, but no documentary evidence for this was revealed. In my opinion, this project 
could not be executed by Bazhenov, because all decorative details are too ascetic, and there are no elements of Russian Style that does not correspond to the master's creative manner. Built in the style of early Russian Neogothic two-storey brick church was erected on the white-stone plinth. The building is square in plan with an apse and square porch attached to the volume of the church. The apse is completed with pediment. The building is crowned with a dome, lucarnes and light drum, where instead of the traditional cupolas raised gothic stone steeple with a cross. A high bell tower crowned by a similar spire, which is a cylindrical two-tiered tower with a circular balcony, is standing on the first tier bushel, resembling a tower of a medieval castle. Decorative finishing of the temple is ascetic, we do not see here any lush decorations. The lower tier of the church closed with barrel vault, and the upper two tiers with windows and a lucarnes and light drum closed with closed vault. The architectural trend of the period was the reason for the restructuring in the Gothic Revival style a number of the older churches. Thus was rebuilt the church of St. Nicholas (Figure 21), built in 16971699 years in the traditional Russian style, and in 1802 received a new Gothic decoration in the form of lancet arches on the facade. At the same time the upper openings quadrangle tier bell tower and square openings of the drum cupolas crowning the main volume of the church, also received lancet arches. (This church was closed in 1932 and later demolished, it was located in an alley Mokrinskiy).
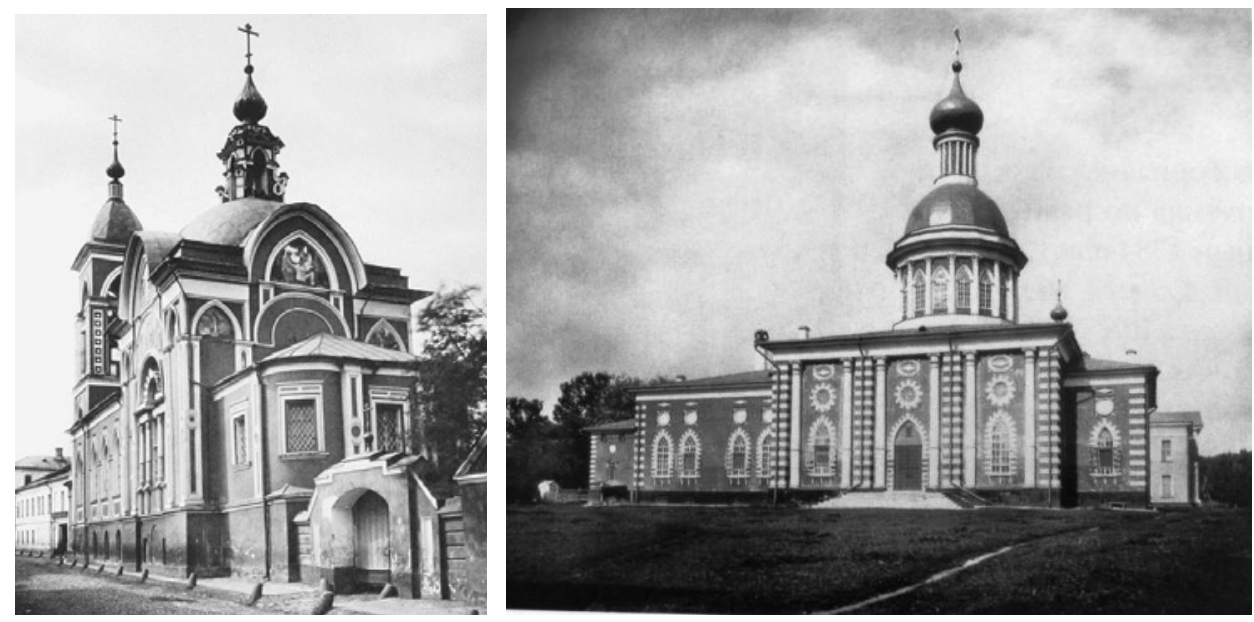

Figure 21. Church of St. Nicholas. Moscow. 1697-99, rebuilt in 1802.

Figure 22. Christmas chapel of Old Believers on Rogozhskoe cemetery. Moscow. 1804. Architect I. Zhukov.

Noteworthy is the fact that in Moscow the churches in early Russian Neogothicstyle continue to be built in the first and the 10-s years of the XIX century, with an influence of the Baroque, in particular the general formation principle of three-dimensional structure of religious buildings. An example of this is the Old Believer Christmas chapel on Rogozhskoe cemetery (Figure 22) (1804, architect I. Zhukov), as well as the Cathedral of the Immaculate Conception of St. Anna Conception monastery (Figure 23), built in 1804-1807. This was the main monastery church, which replaced an older building. Author of the project is believed to be M.F. Kazakov, but there is no documentary evidence of this. In its appearance the temple combines elements of Neogothicand Baroque (it was completely destroyed in the 1930s.). It was quite large and majestic cathedral, square in plan with a semicircular apse. From the west the main volume of its two tiers of windows was adjoined with the refectory and the octagonal three-storey bell tower. The cathedral was completed by massive dome on a square drum with truncated corners. Drum was topped with a tiny cupola and surrounded by four towers with spires. The appearance of the cathedral was heavy and impressive. A more slender proportions had only its bell tower. 


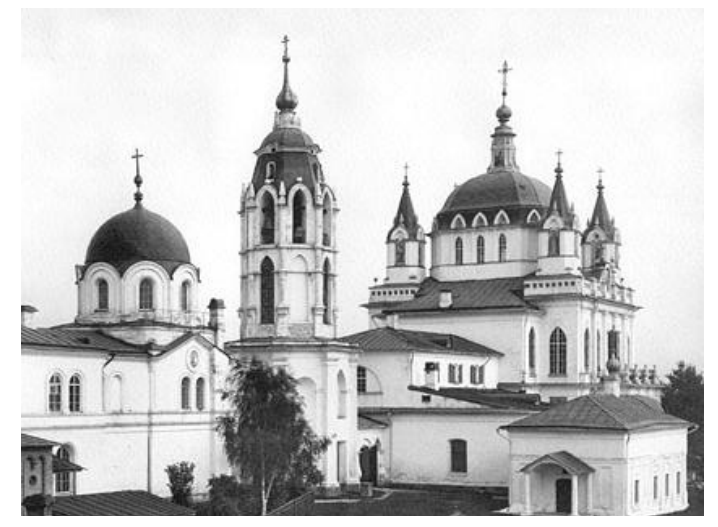

Figure 23. Cathedral of the Immaculate Conception of St. Anna Conception monastery. Moscow. 1804-1807. The architect M.F. Kazakov. Photo of the early XX century.

The Baroque style influenced to the front compositions of some buildings in the style of early Russian neo-gothic, for example the Church of the Saviour in Ivanteevka (Figure 24-27), presumably erected by Alexander Bakarev, in E.O. Batashev manor in 1808. It also shows the mixed gothic and baroque elements, which is especially noticeable in the shape of windows, a very different shape - lancet, curly, three-blade, circular. This church cruciform in plan, was completed with low muffled drum with a dome, cut fanciful lucarnes, and surmounted by a stone spire. Similarly, square bell tower is complete with a bunk and a spire, connected with the main volume of the church through the refectory.
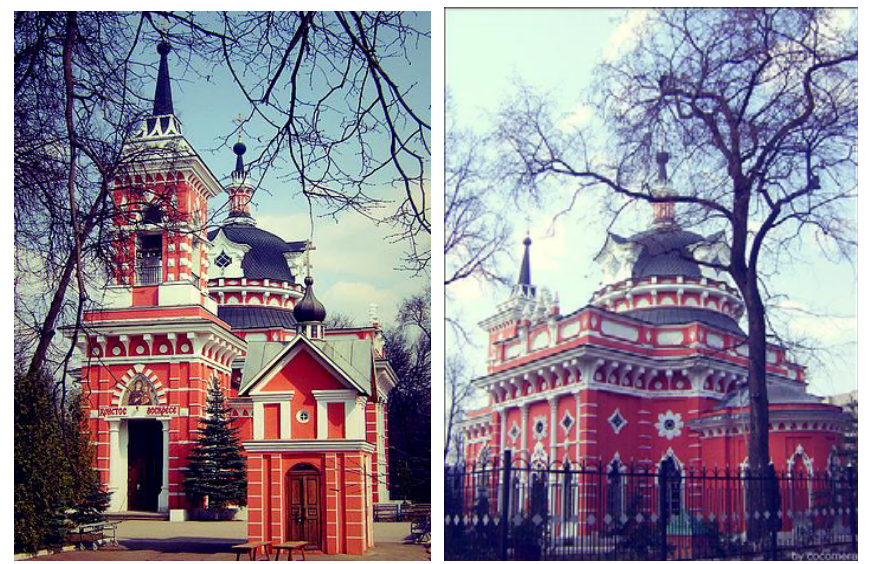

Figure 24, 25. The Church of the Saviour. Ivanteyevka. E.O. Batashev manor. 1808 Architect A.N. Bakarev (?). View from the southwest (left). View from the southeast.
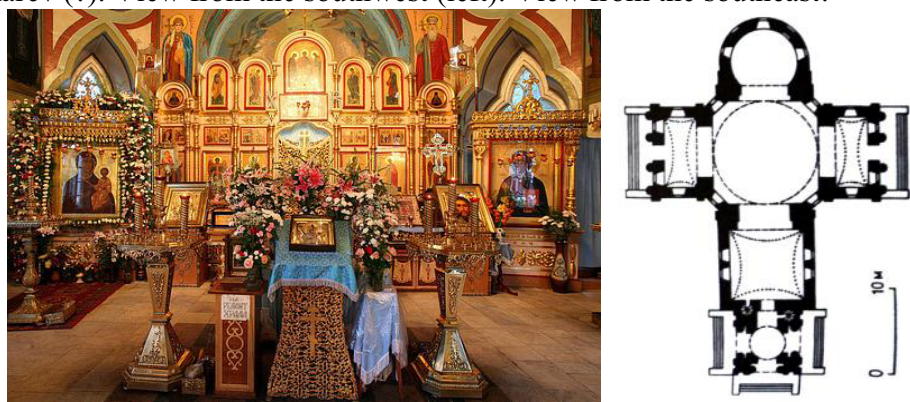

Figure 26, 27. The Church of the Saviour. Ivanteyevka. E.O. Batashev manor. 1808 Architect A.N. Bakarev (?). Interior and plan. 
Another notable example of the connection of baroque planning structure with gothic decorative design is St. Nicholas Church in the village of Tsarevo (1812-1815) $(28,29)$, built in three years, the author of the project is considered to be a pupil of V.I. Bazhenov and M.F. Kazakov - I.V. Egotov. This church was built by the order of the owner of the village Nikolai Durasov. Planning structure of the temple is fairly complex and very unusual: the main church hall is round, from east to adjoin the semicircular apse and the west - two oval aisle and rectangular porch. The main dome rests on eight pillars supporting the central hall. Church completed with spire surrounded by four small spires, mounted on a small octagonal drum resting on the central dome, erected on a high major drum with lancet windows. On the west side of the main dome is located a belfry, octagonal-shaped cupola, completed with five spires. The same turret, but not carrying the belfry functions, located on the east side. Unusual is also a classical frieze encircling the perimeter of the church, and depicts a scene from the Bible, made by sculptor T. Zamaraev. This frieze is supplemented by Gothic frieze below, giving the composition greater integrity.
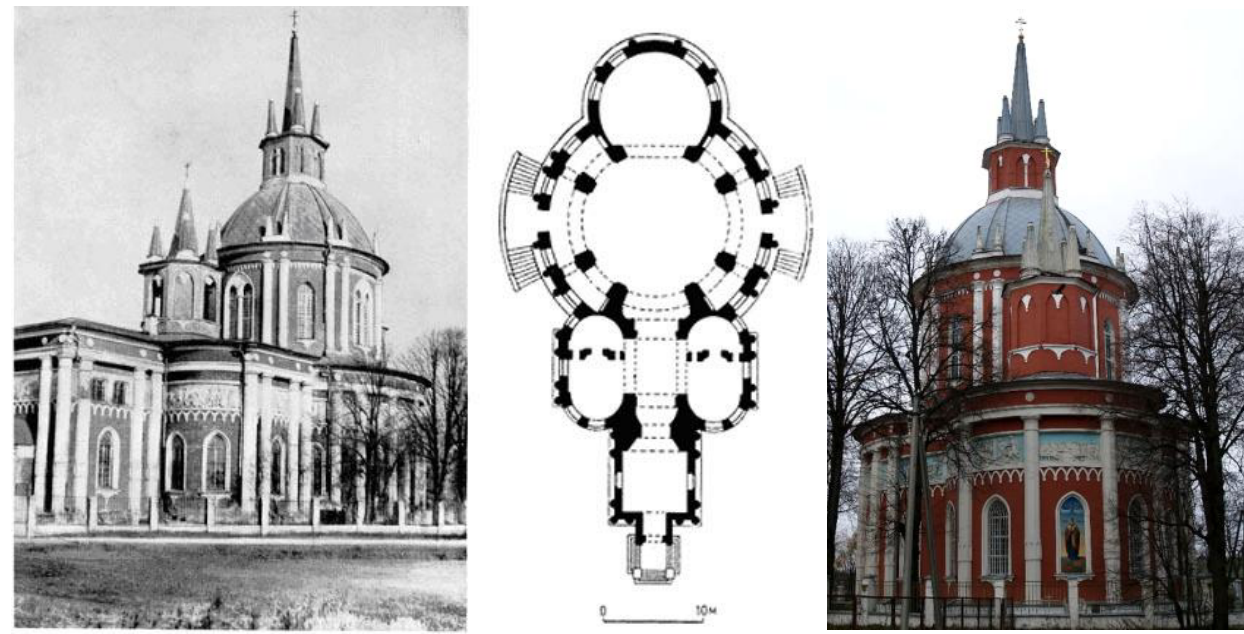

Figure 28.29. St. Nicholas Church. The village of Tsarevo. 1812-1815 years. Architect I.V. Egotov (?). View from the southwest. Plan. View from the east.

Next, you need to mention also the Orthodox chapels, showing the use of Gothic shapes. One of them was erected in 1804 on the project of Fedor Kirillovich Sokolov. It Nicholas Chapel at the Transfiguration Cemetery (Figure 30,31) in Moscow. Previously it was thought that it was designed by Vasily Bazhenov in 1772. This chapel belongs to a complex of buildings of the Old Believers' almshouse built after the plague in 1771 on the expense of Ilya Alekseevich Kavylin. Buildings in the complex included a chapel, the church of St. Nicholas (Figure 32), the bell tower (Figure 33) and the area of the cemetery that was surrounded by a wall with Neogothic towers. This chapel is differs special richness of decorative finishes and is an example of centric composition. Square in plan, it completed with a hemispherical dome, which is crowned with five elegant white stone spires, the central of which is significantly superior to the other in height. Angles of chapel detailed with filigree reinforced cylindrical columns, and topped with tall spires. Its appearance combines Gothic, Old Russian and baroque motifs. 

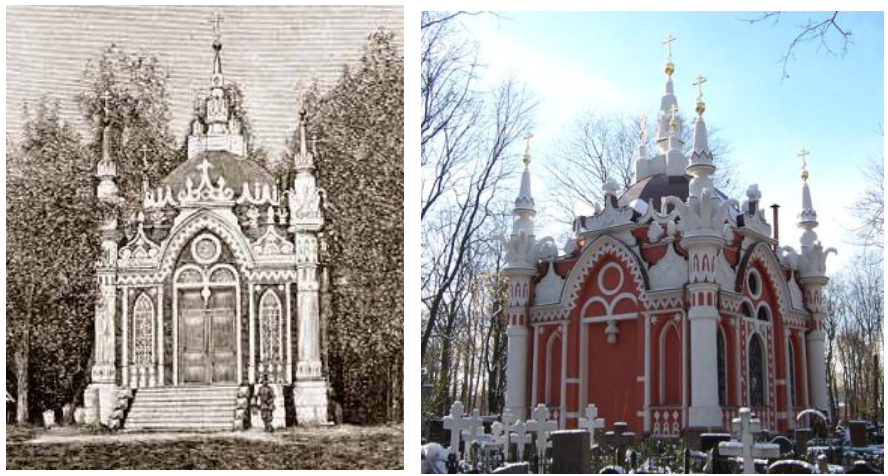

Figure 30, 31. St. Nicholas Chapel at the Transfiguration Cemetery 1804 Architect F.K. Sokolov.
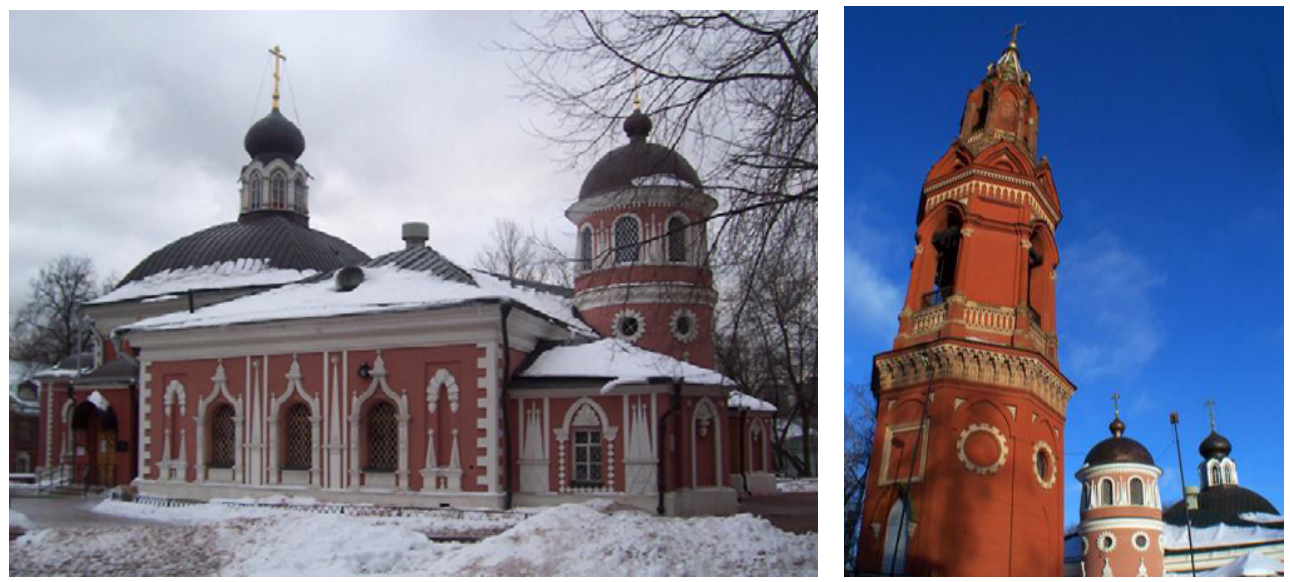

Figure 32. Church of St. Nicholas in the Transfiguration Cemetery 1784-1790. Architect F.K. Sokolov. Figure 33. The bell tower of the church of St. Nicholas. 1784-1790. Architect F.K. Sokolov.

Separately, it must be said about the rebuilding of the Kremlin at the end of the XVIII beginning of XIX century, and in particular on the porch annex to the refectory of the monastery Chudov (Figure 34) in the late 1770s under the direction of M.F. Kazakov. Porch is showing a synthesis of old Russian, classical and gothic motifs, completed with two tetrahedral dome tents and adorned Ivanov area of the Kremlin. later the Moscow Kremlin will receive a lot of Gothic elements.

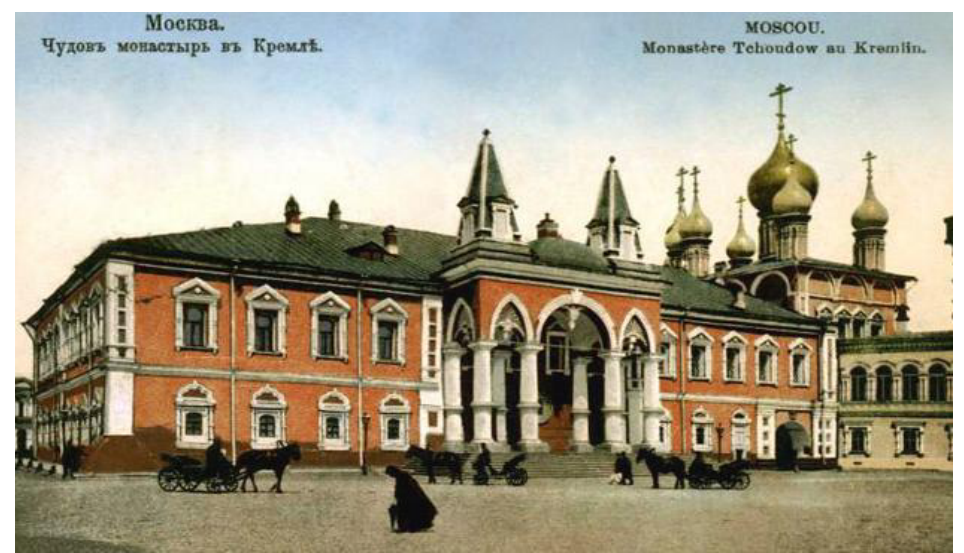

Figure 34. Porch of refectory of the Chudov monastery. 1770s. The architect M.F. Kazakov. 
In 1800-s architect I.V. Egotov creates Resurrection Gate project in Moscow (Figure 35). The gates of these as well as the porch of the refectory of Chudov monastery show a combination of Gothic, classical and Russian styles. Extremely interesting was also unfulfilled bell tower restoration project of the Ivan the Great (Figure 36) made by A.N. Bakarev. This project involves a completely new construction on the site of the Belfry and the Filaret outbuildings, which were destroyed by the retreating French army in October 1812. According to the architect a new bell tower was supposed to be a kind of monument to the victory of Russian arms. At the same time the appearance of the bell tower was supposed to be a fundamentally eclectic: classic Doric colonnade with triangular gables are combined with Gothic pointed arches and rose windows, and the whole composition was completed with Russian bulbous dome. Façade of belfry was supposed to be decorated with the numerous sculptures and bas-reliefs. This project once again confirms the common perception of the European and Russian Middle Ages. In Moscow it continued to 1820s.
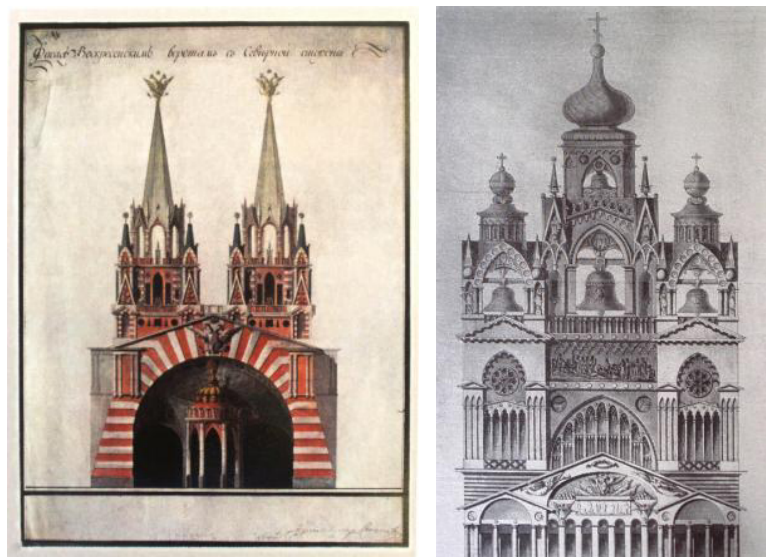

Figure 35. Resurrection Gate project in Moscow. Architect I.V. Egotov. 1800s.

Figure 36. The project of bell tower Ivan the Great restoration. Architect A.N. Bakarev. 1812.

\section{Conclusion}

Concluding the observation of the early Russian Neogothicreligious buildings we need to note the main features: in the stylistic aspect, it is the impact of Russian Style, classicism and baroque architectural appearance on church buildings; typology can be distinguished as Orthodox, Lutheran and Catholic churches, as well as the Orthodox chapels, free-standing bell towers and monastery walls.

\section{References}

1. Architect Yury Felten. To the 250 anniversary since birth. Exhibition catalog: Art (1982) 55 p.

2. M. G. Baranova, "Gothic style" in the Russian architecture of the second half of XVIII (on the example of monuments of St. Petersburg and its suburbs): RGPU of Herzen (2005) $242 \mathrm{p}$.

4. N. A. Evsina, Russian architecture during Catherine II's era (1994) Moskva: Science, 223 p.

5. S. I. Razgonov, Vasily Ivanovich Bazhenov (1985) Moskva: Art, 168 p.

6. I. Yamshanov, V. Goryunov, V. Murgul, Procedia Engineering, 117, 675-684 (2015)

7. I. Yamshanov, V. Murgul, N. Vatin, Applied Mechanics \& Materials, 740, 1192 (2014)

8. I. Yamshanov, V. Goryunov, V. Murgul, Procedia Engineering, 117, 663-674 (2015)

9. I. Yamshanov, V. Goryunov, V. Murgul, N. Vatin. Advanced Materials Research, 1065-1069, 2669-2673 (2015) 